\title{
Detection of highly and minimally leukotoxic Actinobacillus actinomycetemcomitans strains in patients with periodontal disease
}

\section{Detecção de cepas de Actinobacillus actinomycetemcomitans de máxima e mínima leucotoxicidade em pacientes com doença periodontal}

\author{
Sheila Cavalca Cortelli* \\ Antonio Olavo Cardoso Jorge** \\ José Roberto Cortelli*** \\ Shawn Francis Jordan**** \\ Violet Ibyola Haraszthy*****
}

\begin{abstract}
This study examined the prevalence of highly and minimally leukotoxic Actinobacillus actinomycetemcomitans in patients with periodontal disease. Pooled subgingival plaque samples from 136 patients with some form of periodontal disease were examined. Subjects were between 14 and 76 years of age. Clinical examinations included periodontal pocket depth (PD), plaque index (PI) and bleeding index (BI). The obtained plaque samples were examined for the presence of highly or minimally leukotoxic A. actinomycetemcomitans strains by the polymerase chain reaction (PCR). Chi-square and logistic regression were performed to evaluate the results. Forty-seven subjects were diagnosed with gingivitis, 70 with chronic periodontitis and 19 with aggressive periodontitis. According to chi-square there was no significant correlation detected between PD $\left(\chi^{2}=0.73\right)$, PI $\left(\chi^{2}=0.35\right)$, BI $\left(\chi^{2}=0.09\right)$ and the presence of the highly leukotoxic A. actinomycetemcomitans. The highly leukotoxic A. actinomycetemcomitans strains were correlated with subjects that were 28 years of age and younger $\left(\chi^{2}=7.41\right)$. There was a significant correlation between highly leukotoxic $A$. actinomycetemcomitans and aggressive periodontitis $\left(\chi^{2}=22.06\right)$. This study of a Brazilian cohort confirms the strong association between highly leukotoxic $A$. actinomycetemcomitans strains and the presence of aggressive periodontitis.

DESCRIPTORS: Actinobacillus actinomycetemcomitans; Leukotoxin; Gingivitis; Periodontitis; Polymerase chain reaction.

RESUMO: O presente estudo avaliou a prevalência de Actinobacillus actinomycetemcomitans de máxima e mínima leucotoxicidade em individuos com doença periodontal. Foram analisadas amostras de placa bacteriana subgengival de 136 indivíduos, entre 14 e 76 anos de idade, com algum tipo de doença periodontal. Os parâmetros clínicos avaliados incluíram profundidade de sondagem (PS), indice de placa bacteriana (IPB) e índice de sangramento gengival (ISG). A presença de amostras de A. actinomycetemcomitans de máxima e mínima leucotoxicidade foi avaliada por reação em cadeia da polimerase (PCR). Os resultados foram analisados empregando-se teste qui-quadrado e análise de regressão logística. Quarenta e sete indivíduos apresentaram gengivite, 70 indivíduos periodontite crônica e 19 indivíduos periodontite agressiva. O teste qui-quadrado não demonstrou correlação significativa entre $\operatorname{PS}\left(\chi^{2}=0,73\right), \operatorname{IPB}\left(\chi^{2}=0,35\right)$, ISG $\left(\chi^{2}=0,09\right)$ e a presença de amostras de máxima leucotoxicidade. A. actinomycetemcomitans de máxima leucotoxicidade apresentou associação com indivíduos com idade inferior a 28 anos $\left(\chi^{2}=22,06\right)$. Os resultados observados nessa população brasileira confirmam a forte associação existente entre amostras de A. actinomycetemcomitans de máxima leucotoxicidade e periodontite agressiva.
\end{abstract}

DESCRITORES: Actinobacillus actinomycetemcomitans; Leucotoxina; Gengivite; Periodontite; Reação em cadeia da polimerase.

\footnotetext{
*Assistant Professor, Microbiology and Periodontics; ***Assistant Professor, Periodontics - University of Taubaté.

**Full Professor, Microbioloy and Immunology, State University of São Paulo; $* * * *$ Master Degree; $* * * *$ Assistant Professor - State University of New York at Buffalo, School of Dental Medicine.
} 
Cortelli SC, Jorge AOC, Cortelli JR, Jordan SF, Haraszthy VI. Detection of highly and minimally leukotoxic Actinobacillus actinomycetemcomitans strains in patients with periodontal disease. Pesqui Odontol Bras 2003;17(2):183-8.

\section{INTRODUCTION}

The presence of periodontal pathogens can be frequently detected in healthy subjects. This indicates that not all humans are equally susceptible and/or that there is variation in virulence and pathogenic potential (Tonetti e Mombelli ${ }^{23}$, 1999; Zadeh et $\left.a ._{.}{ }^{26}, 1999\right)$. Bacteria associated with periodontal disease have a number of virulence factors such as endo- and exotoxins, that can directly damage host tissues, and immune evasion strategies which shield the bacteria from host defenses.

Every strain of $A$. actinomycetemcomitans studied to date is resistant to serum-mediated killing. They are not killed by unseparated serum and any serum component by implication, which would include the membrane attack complex, platelet-derived $\beta$-lysin, acute phase proteins and lysozyme. To clear an infection by a serum-resistant organism necessarily involves host phagocytes (Zadeh et al. ${ }^{26}$, 1999). However, A. actinomycetemcomitans has been shown to be capable of inhibiting polymorphonuclear leukocytes chemotaxis (Van Dyke et $a ._{.}^{24}$, 1982; Fives-Taylor et $\left.a l^{7}, 1996\right)$. Furthermore, phagocytosis inhibition is associated with $A$. actinomycetemcomitans $\mathrm{Fc}$ binding proteins. A. actinomycetemcomitans can also inhibit the leukocytes fusion with lysosomes (Fives-Taylor et al. ${ }^{8}$, 1999).

A. actinomycetemcomitans produce a leukotoxin (ltx) that is an RTX (repeats in toxin) toxin. The RTX family members share similar gene organization and are expressed from an operon consisting of four genes that are designated $\mathrm{C}$ (ltxC), A (ltxA), B (ltxB) and D (ltxD) in transcriptional order. The structural gene is designated as the gene A and the three remaining genes flanking the A gene are required to activate and transport the toxin (Lally et $a .^{12}$, 1989). Leukotoxins are cell-specific. The toxin binds to neutrophils, monocytes and a subset of lymphocytes (Zadeh et al. $\left.{ }^{26}, 1999\right)$. Cell lysis might be induced by the rapid formation of highly conductive ion channels that lead to membrane depolarization, loss of intracellular $\mathrm{K}^{+}$, osmotic swelling, and subsequently cell death (Slots $^{20}$, 1994; Lally et al. ${ }^{12}$, 1996; Karakelian et al. ${ }^{11}, 1998$; Fives-Taylor et al. $\left.{ }^{8}, 1999\right)$. The expression of leukotoxins is tightly regulated in many strains, although some strains produce high levels of leukotoxins (Brogan et al. ${ }^{5}, 1994$; Mombelli et al. ${ }^{15}$, 1999; Paju et al. $\left.{ }^{17}, 2000\right)$. The promoter re- gions of high producers have a $530 \mathrm{bp}$ deletion that may be involved in repressing leukotoxin expression (Brogan et $\left.a ._{.}{ }^{4}, 1994\right)$. Leukotoxins may protect $A$. actinomycetemcomitans against phagocytosis by human polymorphonuclear leukocytes (Johansson et al. $\left.{ }^{10}, 2000\right)$. Patients with aggressive periodontitis were shown to have a substantially higher prevalence of highly leukotoxic strains than chronic periodontitis individuals (Zambon et al. ${ }^{28}$, 1996; Haraszthy et al. ${ }^{9}, 2000$ ).

The aim of the present study was to examine the prevalence of highly and minimally leukotoxic Actinobacillus actinomycetemcomitans in patients with periodontal disease.

\section{MATERIALS AND METHODS Subject population}

A total of 136 subjects, males and females, aged from 14 to 76 years with gingivitis (47), chronic (70) and aggressive (19) periodontitis were enrolled in this study. Individuals were previously classified as gingivitis, chronic or aggressive periodontitis patients, based upon clinical and radiographic findings (periodontal probing depth - PD, loss of clinical attachment and periapical radiographs) and on the diagnostic criteria presented in the World Workshop of Periodontology 1999 (AAP ${ }^{2}$, 1999). Clinical examinations also included Plaque Index - PI and Bleeding Index - BI (Ainamo, Bay ${ }^{1}$, 1975).

Subjects were excluded if any of the following conditions were detected: use of systemic antibiotic in the previous 6 months and periodontal therapy undertaken less than 12 months before the study. All subject participation was preceded by approval of all protocols by the appropriate institutional review board and the obtainment of a signed consent from participants.

\section{Microbial Sampling and Polymerase Chain Reaction}

Pooled subgingival plaque samples were taken from five periodontal sites (> PD). After the removal of supragingival plaque, subgingival plaque samples were taken with sterile paper points (Tanari, Tanariman Industrial Ltda., Manacapuru, Brazil) inserted to the depth of the pockets or sulci from the mesial aspect of five different teeth from each subject. The paper points were removed after 15 seconds, and immediately placed in phosphate-buffered saline $(\mathrm{pH} \mathrm{7.4)}$ on ice. The bacterial cells were pelleted at $12,000 \mathrm{x} \mathrm{g}$ for 1 minute in a 
Cortelli SC, Jorge AOC, Cortelli JR, Jordan SF, Haraszthy VI. Detection of highly and minimally leukotoxic Actinobacillus actinomycetemcomitans strains in patients with periodontal disease. Pesqui Odontol Bras 2003;17(2):183-8.

microfuge (Eppendorf) and DNA was isolated from the samples (Instagene Purification Matrix, Bio Rad, Hercules, USA).

PCR was performed using a thermocycler (Perkin Elmer Cetus) with Taq polymerase (Amershan, Arlington Heights, USA). Using previously published sequences (Brogan et al. $\left.{ }^{5}, 1994\right), 2$ oligonucleotide primers were used to the $A$. actinomycetemcomitans leukotoxin promoter region:

- A - 5'-GCAGGATCCATATTAAATCTCCTTGT-3';

- B - 5'-GCGGTCGACAACCTGATAACAGTATT-3'.

They were used to amplify either a 492 base pair product characteristic of highly leukotoxic $A$. actinomycetemcomitans or a 1022 base pair product characteristic of minimally leukotoxic $A$. actinomycetemcomitans. PCR was performed using standard conditions. The reaction mixture consisted of $100 \mu \mathrm{l}$ of $10 \mathrm{mM}$ Tris- $\mathrm{HCl} \quad \mathrm{pH} 8.3$ (Amershan, Arlington Heights, USA), $50 \mathrm{mM} \mathrm{KCl}$ (Amershan, Arlington Heights, USA), $1.5 \mathrm{mM}$ $\mathrm{MgCl}_{2}$ (Amershan, Arlington Heights, USA), $100 \mu \mathrm{M}$ each of dATP, dCTP, dGTP, dTTP (Amershan, Arlington Heights, USA), $0.001 \%$ (w/v) gelatin, $100 \mathrm{ng}$ of each primer (Invitrogen/Gibco, San Diego, USA), 0.5 U Taq polymerase, and $100 \mathrm{ng}$ of genomic DNA. The thermocycle profile was $25 \mathrm{cy}-$ cles of 30 seconds at $95^{\circ} \mathrm{C}, 30$ seconds at $55^{\circ} \mathrm{C}$, and 30 seconds at $72^{\circ} \mathrm{C}$. The amplification products were analyzed by electrophoresis in $2 \%$ submarine agarose gels (Sigma, Dorset, UK) and visualized by UV illumination (Bio Rad, Hercules, USA) following ethidium bromide (Amershan, Arlington Heights, USA) staining. These agarose gels were compared with both positive (JP2 and 652 strains) and negative controls.

\section{Statistical analysis}

Chi-square and logistic regression were performed to evaluate the results. The level of significance considered was set at $\mathrm{p}<0.05$. The relation between variants and periodontal diagnosis was established by logistic regression. Age, gender, smoking, PD, PI, BI, PCR detection and highly or minimally leukotoxic A. actinomycetemcomitans were considered in separated or multiple analyses. The probability of aggressive periodontitis - P(AP) was calculated as follows:

$\mathrm{P}(\mathrm{AP})=\frac{1}{1+\exp (5.58-0.42 \text { age }+0.74 \text { periodontal pocket depth })}$

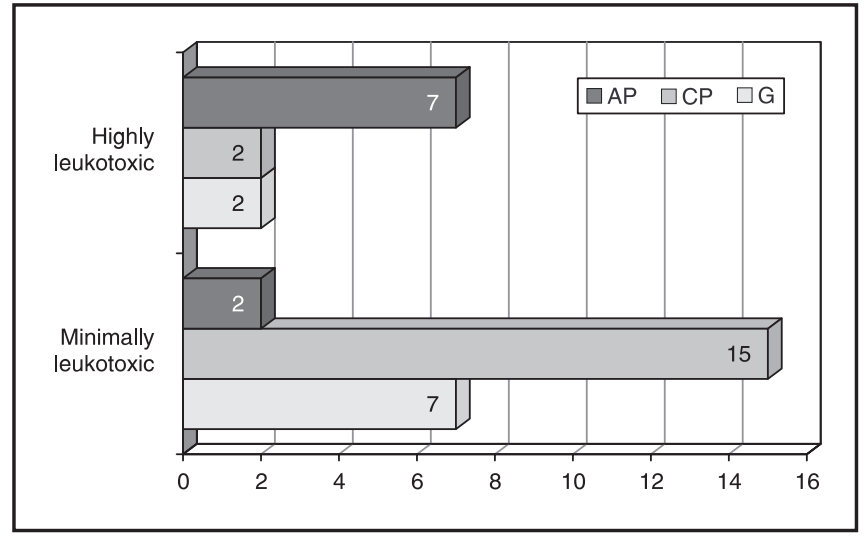

GRAPH 1 - Highly and minimally leukotoxic Actinobacillus actinomycetemcomitans according to periodontal status. $\mathrm{G}$ - gingivitis ( $\mathrm{n}=47$ ); $\mathrm{CP}$ - chronic periodontitis $(\mathrm{n}=70) ;$ AP - aggressive periodontitis $(\mathrm{n}=19)$.

\section{RESULTS}

Graph 1 shows the distribution of highly and minimally leukotoxic A. actinomycetemcomitans. The major prevalence of highly leukotoxic $A$. actinomycetemcomitans was observed in aggressive periodontitis subjects followed by chronic periodontitis and gingivitis $\left(\chi^{2}=22.06\right)$. No statistically significant difference was observed between gingivitis and chronic periodontitis related to highly leukotoxic $A$. actinomycetemcomitans $\left(\chi^{2}=0.17\right)$. In contrast, highly leukotoxic $A$. actinomycetemcomitans was correlated with subjects 28 years of age and younger $\left(\chi^{2}=7.41\right)$.

Minimally leukotoxic $A$. actinomycetemcomitans showed no correlation with periodontal status $\left(\chi^{2}=0.91\right)$. No association between PD $\left(\chi^{2}=0.73\right)$, PI $\left(\chi^{2}=0.35\right)$ and BI $\left(\chi^{2}=0.09\right)$ and highly and minimally leukotoxic $A$. actinomycetemcomitans was detected.

Separated logistic regression analyses showed correlation between periodontal status and age, highly leukotoxic $A$. actinomycetemcomitans and PI (Table 1). Multiple logistic regression analyses showed correlation between periodontal disease, age and PD (Table 2).

The probability of aggressive periodontitis was calculated. Graph 2 shows the results. The minimum and maximum values of PD found among all subjects included in the present study were applied in multiple logistic regression. Age was also considered for analyses. 
Cortelli SC, Jorge AOC, Cortelli JR, Jordan SF, Haraszthy VI. Detection of highly and minimally leukotoxic Actinobacillus actinomycetemcomitans strains in patients with periodontal disease. Pesqui Odontol Bras 2003;17(2):183-8.

TABLE 1 - Estimate coefficient, p value and statistically significance established by logistic regression related to isolated analyses of each considered variant.

\begin{tabular}{l|c|c|l}
\hline \hline \multicolumn{1}{c|}{ Variants } & $\begin{array}{c}\text { Coeffi- } \\
\text { cient }\end{array}$ & p value & \multicolumn{1}{|c}{ Results } \\
\hline Age & -0.33 & 0.00 & $\begin{array}{l}<\text { age } \\
>\text { probability } \\
\text { of AP }\end{array}$ \\
\hline $\begin{array}{l}\text { Highly leukotoxic } A . \text { ac- } \\
\text { tinomycetemcomitans }\end{array}$ & 2.99 & 0.00 & $\begin{array}{l}\text { Presence } \\
\text { probability } \\
\text { of AP }\end{array}$ \\
\hline Plaque index & -0.30 & 0.05 & $\begin{array}{l}\text { No plaque } \\
\text { of AP }\end{array}$ \\
\hline Bleeding index & -0.90 & 0.10 & ns \\
\hline Smoking & -0.62 & 0.28 & ns \\
\hline $\begin{array}{l}\text { Minimally leukotoxic } A . \\
\text { actinomycetemcomitans }\end{array}$ & 0.73 & 0.29 & ns \\
\hline PCR detection & 0.47 & 0.32 & ns \\
\hline $\begin{array}{l}\text { Periodontal } \\
\text { pocket depth }\end{array}$ & -0.11 & 0.55 & ns \\
\hline Gender & 0.06 & 0.92 & ns \\
\hline \hline
\end{tabular}

AP - aggressive periodontitis; PCR detection - presence of A. actinomycetemcomitans; PCR - polymerase chain reaction; ns - not significant.

TABLE 2 - Results of multiple logistic analyses.

\begin{tabular}{c|c|c}
\hline \hline Variant & Age & Periodontal pocket depth \\
\hline Coefficient & -0.42 & 0.74 \\
\hline $\mathrm{p}$ value & 0.00 & 0.05 \\
\hline \hline
\end{tabular}

\section{DISCUSSION}

A. actinomycetemcomitans is an important pathogen in some forms of periodontitis. Aggressive periodontitis is the most notorious disease associated with $A$. actinomycetemcomitans. The prevalence of this pathogen is nearly $90 \%$ in aggressive periodontitis and $30-50 \%$ in severe chronic periodontitis. Furthermore, one of the most important virulence factors of $A$. actinomycetemcomitans is leukotoxin (Lally et al. ${ }^{12}, 1996$; Karakelian et al. ${ }^{11}$, 1998; Fives-Taylor et al. ${ }^{8}, 1999$; Zadeh et al. ${ }^{26}$, 1999). In the present study, the periodontal status was associated with highly leukotoxic $A$. actinomycetemcomitans. There was significant correlation between highly leukotoxic strain and ag- gressive periodontitis $\left(\chi^{2}=22.06\right)$ (Graph 1$)$. Additionally, we observed that the highly leukotoxic $A$. actinomycetemcomitans strain was correlated with subjects 28 years of age and younger $\left(\chi^{2}=7.41\right)$. These data agree with the results obtained by Ávila-Campos, Velásquez-Meléndez ${ }^{3}$ (2002) who observed that $A$. actinomycetemcomitans was associated with disease in fifty Brazilian patients with clinical and radiographic evidence of alveolar bone loss confined to the molar and incisor teeth. Nakagawa et al. ${ }^{16}, 2001$, analyzed the serumal and salivary levels of antibodies against the leukotoxin produced by $A$. actinomycetemcomitans in Brazilian patients with aggressive periodontitis and in healthy controls. The authors found significantly higher serumal levels of IgG in patients with aggressive periodontitis, when they were compared with the healthy controls. However, Lima et al. ${ }^{13}$, 2001 , isolated a high leukotoxin producer from a healthy subject and moderate producers from periodontal disease patients.

On the other hand, no relation was observed between plaque index $\left(\chi^{2}=0.35\right)$, bleeding index $\left(\chi^{2}=0.09\right)$ and highly and minimally leukotoxic $A$. actinomycetemcomitans. These data are in accordance with other studies which strongly showed that there is more probability to detect $A$. actinomycetemcomitans when clinical signs of inflammation were evident (Mombelli et al. ${ }^{14}$, 1995; Zambon et al. $^{27}$, 1994; Tanner et al. $\left.{ }^{22}, 1996\right)$. Particularly in chronic periodontitis subjects, $A$. actinomycetemcomitans was weakly related to the bleeding index, while there was no correlation between the organism and any clinical index in aggressive periodontitis subjects (Bonta et al. ${ }^{4}$ 1985; Renvert et al. ${ }^{18}$ 1997; Shiloah e Patters ${ }^{19}$, 1997).

When periodontal pocket depth is considered, different authors have related A. actinomycetemcomitans to deeper pockets (Slots et al. ${ }^{21}$, 1980; Wolff et al. $^{25}$, 1993; Zambon ${ }^{27}$, 1994; Tanner et al. ${ }^{22}$, 1996). In the present study no correlation was observed between periodontal pocket depth and highly and minimally leukotoxic A. actinomycetemcomitans. However, multiple logistic regression analyses showed that periodontal pocket depth was related to highly leukotoxic $A$. actinomycetemcomitans $(\mathrm{p}<0.05)$.

Separated logistic regression was applied to analyze the relation between risk factors and periodontal status (Table 1). Age and PD were strongly associated with aggressive periodontitis $(p<0.05)$ according to multiple logistic regression (Table 2). 
Cortelli SC, Jorge AOC, Cortelli JR, Jordan SF, Haraszthy VI. Detection of highly and minimally leukotoxic Actinobacillus actinomycetemcomitans strains in patients with periodontal disease. Pesqui Odontol Bras 2003;17(2):183-8.

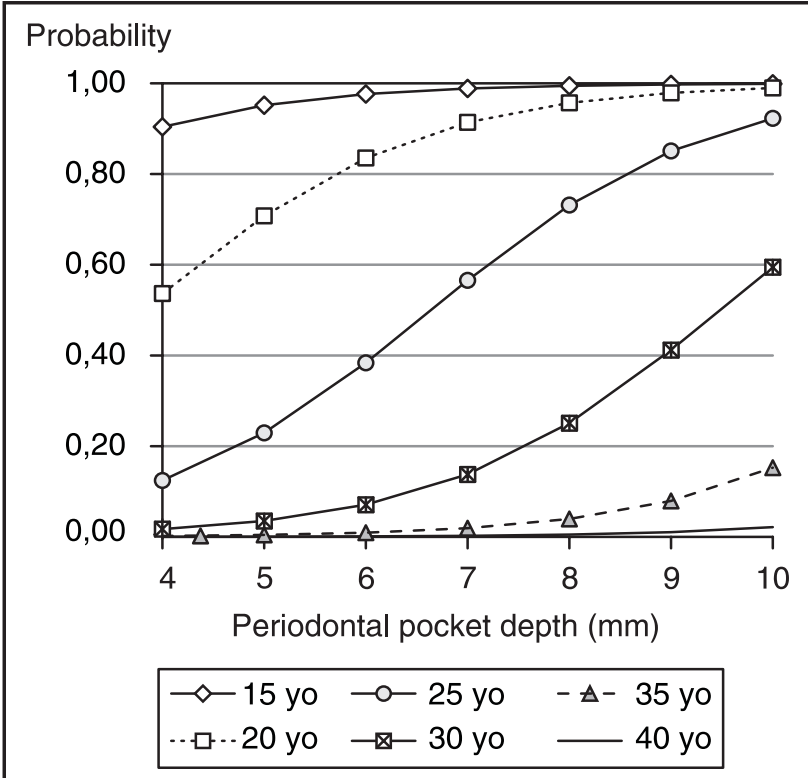

GRAPH 2 - Probability of aggressive periodontitis according to age and periodontal pocket depth $(\mathrm{mm})$ of the studied population; yo: years old.

Different ages and values of PD found in the present study originated a diagram of probabilities for aggressive periodontitis. Subjects 20 years of age or younger and PD between 9 and $10 \mathrm{~mm}$ showed $100 \%$ of probability of aggressive periodontitis. On the other hand, subjects 40 years of age or older, even showing similar PD (9 to $10 \mathrm{~mm}$ ) had probability close to zero to exhibit aggressive periodontitis (Graph 2). The present research showed an association between age, PD and aggressive periodontitis.

\section{REFERENCES}

1. Ainamo J, Bay I. Problems and proposals for recording gingivitis and plaque. Int Dent J 1975;25:229-35.

2. American Academy of Periodontology. Ann Periodontol 1999;4:18-9.

3. Ávila-Campos MJ, Velásquez-Meléndez G. Prevalence of putative periodontopathogens from periodontal patients and healthy subjects in São Paulo, SP, Brazil. Rev Inst Med Trop S Paulo 2002;44:1-5.

4. Bonta Y, Zambon JJ, Genco RJ, Neiders ME. Rapid identification of periodontal pathogens in subgingival plaque: comparison of indirect immunofluorescence microscopy with bacterial culture for detection of Actinobacillus actinomycetemcomitans. J Dent Res 1985;64:793-8.

5. Brogan JM, Lally ET, Poulsen K, Killian M, Demuth DR. Regulation of Actinobacillus actinomycetemcomitans leukotoxin expression: analysis of the promoter regions of
A. actinomycetemcomitans is implicated in aggressive periodontitis and it is generally considered a major etiologic microorganism in this form of disease. However, the role of the pathogen in chronic periodontitis is more difficult to make clear since A. actinomycetemcomitans is found in a much more microbiologically complex and diverse plaque ecology compared to A. actinomycetemcomitans infections in aggressive periodontitis Zambon $^{27}$, 1994). The relationships between bacteria in chronic periodontitis are frequent. For example, $P$. gingivalis and $P$. intermedia produce proteases that can decrease the toxicity of $A$. actinomycetemcomitans. Thus, in some patients A. actinomycetemcomitans can exhibit a complementary role in developing periodontal disease (Chen, Slots $\left.{ }^{6}, 1999\right)$.

\section{CONCLUSIONS}

The major prevalence of highly leukotoxic $A$. actinomycetemcomitans was observed in aggressive periodontitis. Minimally leukotoxic strains showed no correlation with periodontal status. This study of a Brazilian cohort confirms the strong association between highly leukotoxic $A$. actinomycetemcomitans strains and the presence of aggressive periodontitis.

\section{ACKNOWLEDGEMENTS}

This work was supported in part by University of Taubaté (UNITAU) and Paulista State University (UNESP). The authors are grateful to Doctor Joseph J. Zambon for their technical assistance at the State University of New York at Buffalo.

leukotoxic and minimally leukotoxic strains. Infect Immun 1994;62:501-8.

6. Chen C, Slots J. Microbiological tests for Actinobacillus actinomycetemcomitans and Porphyromonas gingivalis. Periodontol 2000 1999;20:53-64.

7. Fives-Taylor PM, Meyer DH, Mintz KP. Virulence factors of the periodontopathogen Actinobacillus actinomycetemcomitans. J Periodontol 1996;67:291-7.

8. Fives-Taylor PM, Meyer DH, Mintz KP, Brissette C. Virulence factors of Actinobacillus actinomycetemcomitans. Periodontol 2000 1999;20:136-67.

9. Haraszthy VI, Hariharan G, Tinoco EMB, Cortelli JR, Lally ET, Davis E, et al. Evidence for the role of highly leucotoxic Actinobacillus actinomycetemcomitans in the pathogenesis of localized juvenile and other forms of early onset periodontitis. J Periodontol 2000;71:912-22. 
Cortelli SC, Jorge AOC, Cortelli JR, Jordan SF, Haraszthy VI. Detection of highly and minimally leukotoxic Actinobacillus actinomycetemcomitans strains in patients with periodontal disease. Pesqui Odontol Bras 2003;17(2):183-8.

10. Johansson A, Sandstrom G, Claesson R, Hanstrom L, Kalfas S. Anaerobic neutrophil-dependent killing of Actinobacillus actinomycetemcomitans in relation to the bacterial leukotoxicity. Eur J Oral Sci 2000;108:136-46.

11. Karakelian D, Lear JD, Lally ET, Tanaka JC. Characterization of Actinobacillus actinomycetemcomitans leukotoxin pore formation in HL60 cells. Biochem Biophys Acta 1998;1406:175-87.

12. Lally ET, Kieba IR, Golub EE, Lear JD, Tanaka JC. Structure/function aspects of Actinobacillus actinomycetemcomitans leukotoxin. J Periodontol 1996;67:298-308.

13. Lima FL, Farias FF, Campos PC, Totola AH, Tavares CAP, Costa JE, et al. Leukotoxic activity of Actinobacillus actinomycetemcomitans isolated from human and non-human primates. Braz J Microbiol 2001; 32: 250-6.

14. Mombelli A, Rutar A, Lang NP. Correlation of the periodontal status 6 years after puberty with clinical and microbiological conditions during puberty. J Clin Periodontol 1995;2:300-5.

15. Mombelli A, Gmur R, Lang NP, Corbert E, Frey J. Actinobacillus actinomycetemcomitans in Chinese adults: serotype distribution and analysis of the leukotoxin gene promoter locus. J Clin Periodontol 1999;26:505-10.

16. Nakagawa RI, Guazeli-Amin V, Hidalgo MM, Trevisan Jr W, Itano EN. Anticorpos antileucotoxina contra Actinobacillus actinomycetemcomitans em amostras de soro e saliva de pacientes com periodontite juvenil localizada. Pesqui Odontol Bras 2001;15:5-11.

17. Paju S, Carlson P, Jousimies-Somer H, Asikainen S. Heterogeneity of Actinobacillus actinomycetemcomitans strains in various human infections and relationships between serotype, genotype, and antimicrobial susceptibility. J Clin Microbiol 2000;38:79-84.

18. Renvert S, Dahlén G, Snyder B. Clinical and microbiological effects of subgingival antimicrobial irrigation with citric acid as evaluated by an enzyme immunoassay and culture analysis. J Periodontol 1997;68:346-52.
19. Shiloah J, Patters MR, Dean JW, Bland P, Toledo G. The survival rate of Actinobacillus actinomycetemcomitans, Porphyromonas gingivalis, and Bacteroides forsythus, following 4 randomized treatment modalities. J Periodontol 1997;68:720-8.

20. Slots J. A. actinomycetemcomitans. In: Nisengard RJ, Newman MG. Oral Microbiology and Immunology. $2^{\text {nd }}$ ed. Philadelphia: Saunders; 1994. P.218-27.

21. Slots J, Reynolds HS, Genco RJ. Actinobacillus actinomycetemcomitans in human periodontal disease: a cross sectional microbiological investigation. Infect Immun 1980;29:1013-20.

22. Tanner A, Kent R, Maiden MFJ, Taubman MA. Clinical, microbiological and immunological profile of healthy, gingivitis and putative active periodontal subjects. J Periodontal Res 1996;31:195-204.

23. Tonetti MS; Mombelli A. Early onset periodontitis. Ann Periodontol 1999;4:39-52.

24. Van Dyke TE, Bartholomew E, Genco RJ, Slots J, Levine MJ. Inhibition of neutrophil chemotaxis by soluble bacterial products. J Periodontol 1982;53:502-8.

25. Wolff LF, Aeppli M, Pihlstrom B, Anderson L, Stoltenberg J, Osborn $\mathrm{J}$, et al. Natural distribution of 5 bacteria associated with periodontal disease. $\mathrm{J}$ Clin Periodontol 1993;20:699-70.

26. Zadeh HH, Nichols FC, Miyasaki KT. The role of the cell-mediated immune response to Actinobacilus actinomycetemcomitans and Porphyromonas gingivalis in periodontitis. Periodontol 2000 1999;20:239-88.

27. Zambon JJ. Actinobacillus actinomycetemcomitans in adult periodontitis. J Periodontol 1994;65:892-3.

28. Zambon JJ, Haraszthy VI, Hariharan G, Rally ET, Demuth DR. The microbiology of early-onset periodontitis: association of highly leukotoxic Actinobacillus actinomycetemcomitans strains with localized juvenile periodontitis. J Periodontol 1996;67:282-90.

Recebido para publicação em 04/10/02 Enviado para reformulação em 19/03/03 Aceito para publicação em 11/04/03 